原発か転移かわからない悪性腫瘍

\title{
原発か転移かわからない悪性腫瘍
}

\author{
清原 隆宏 \\ 福井大学医学部皮㢆科
}

要旨 皮䖉に生じる悪性腫瘍が原発か転移かを適切に判断することは非常に重要である。皮 虐原発であるにもかかわらず転移を疑わせる特殊型，転移であるにもかかわらず皮膚原発に類 似する症例を中心に解析し，文献的に考察した。

転移性有棘細胞癌は，表皮との連続のない境界明瞭な腫瘤を形成する。皮虞原発未分化有棘 細胞癌は単層上皮型ケラチンが陽性になり, 転移性腺癌に類似することがある。膀胱癌, 子宮 癌・腟癌, 直腸肛門癌は外院部・肛門周囲にパジェット現象を生じ, 真皮・粘膜固有層の深部 にリンパ管内腫瘍塞栓が観察されることがある。また, パジェット病とパジェット現象の鑑別 にGCDFP 15 とサイトケラチン 20 の染色が有用である。眼瞼原発の印鑑細胞癌はサイトケラ チン 20 陽性である。原発性真皮メラノーマという表皮内病変を有さない特殊型が存在する。 clear cell sarcoma の臨床病理組織学的特徵を有するものには原発と転移の 2 種類がある。 epidermotropic metastatic malignant melanoma は in situ melanomaに類似することがある。 その他, 原発か転移かの判断には time course が非常に重要である。

\section{Malignant skin tumors that are difficult to distinguish as primary or metastatic}

Takahiro KIYOHARA

Department of Dermatology, University of Fukui

It is very important for dermatologists to determine whether malignant skin tumors are primary or metastatic. The determination affects the treatment and prognosis of these lesions. I present cases of malignant skin tumors that were difficult to distinguish as primary or metastatic.

Metastatic SCC is not continuous with the overlying epidermis and well demarcated pathologically. Poorly differentiated SCC demonstrates a pseudogland formation, and reveals a positivity for simple epithelial keratin proteins and vimentin. Immunohistochemical panels of GCDFP 15 and cytokeratin 20 are very useful in distinguishing between primary and secondary extramammary Paget's disease. It is important to recognize the existence of primary dermal melanomas. Metastatic melanoma sometimes demonstrates the morphological characteristics of clear cell sarcoma. Epidermotropic metastatic malignant melanoma can simulate primary melanoma in situ. [Skin Cancer (Japan) 2006 ; 21 :286-292]

Key words : primary, metastatic, SCC, paget, melanoma 


\section{はじめに}

悪性腫瘍の診療に従事するなかで，しばしば 原発か転移かの判断に迷う症例に遭遇すること がある。目の前の腫湯が原発か転移かにより， 治療法は全く異なり，患者の予後も違ってく る。原発か転移かを適切に判断することは非常 に重要である。

扁平上皮は皮膚以外の多くの臓器に存在して おり，有棘細胞癌（SCC）は転移癌との鑑別が 問題になることがある。基底細胞癌は，遠隔転 移を生じることはほとんどない。乳房外パ ジェット病および皮膚付属器癌は, 内臓腺癌が パジェット現象を起こすことがあり，鑑別に苦 慮することがある。悪性黒色腫は高率に遠隔転 移を起こしうる悪性度の高い腫瘍である。本稿 では有棘細胞癌, 乳房外パジェット病および皮 虚付属器癌, 覀性黒色腫について, 原発か転移 かが議論になる症例について供覧する。

\section{有棘細胞癌関連症例}

症例 1：85 歳, 男性

現病歴：19 力月前, 食道の高分化型 SCCに 対し, 食道全摘出術, 後縦隔胃管再建術を施行 されている。2 カ月前, 上口唇に紅色腫瘤が出 現し，3回切開排膿された。

現 症：上口唇に $20 \times 18 \mathrm{~mm}$ 大の紅色腫瘤 がある。

病理組織(皮虐)：癌真珠を伴う高分化型SCC。 境界明瞭な腫瘍塊を形成し，表皮との連続はな い。

免疫組織化学：皮膚, 食道ともに染色性が極 めて類似。

治療と経過：本症例は食道 SCC からの転移 として全く矛盾しないが, 全身検索で他部位へ の転移が確認できず，転移癌と断定できなかっ た。腫瘤出現後 2 カ月の時点では画像検査で異 常所見がなく, 術前補助療法の後に腫瘤を切除
した。しかし，術直後の肝臓の造影 CT で肝多 発転移が確認され，その後すぐに永眠された。

診断と考察：本症例は食道癌の皮膚転移であ る。表皮との連続がない境界明瞭な腫瘤という 典型的な所見を呈したにもかかわらず，当初か ら転移癌と確定できず，最終的には上口唇に発 生後, 4 カ月余で他臓器転移を起こしたという time course から, 診断が確定できた。

症例 $2: 73$ 歳, 女性

現 症：右煩部の熱傷瘕痕上に, $35 \times 28 \mathrm{~mm}$ 大，ドーム状に隆起する，びらんを伴う肉芽様 の紅色腫瘤がある（図1 a)。

病理組織：腫瘍は真皮中心に増殖し，一部で は腔形成が著明である（図 $1 \mathrm{~b}$ )。病巣辺縁で 日光角化症が存在し, 表皮から連続して棘融解 細胞, 紡錘形細胞に移行しており, 棘融解を呈 した pseudoglandular な部分と紡錘形細胞から なる storiform な部分が移行している。核異型 は著明である。

免疫組織化学 : 全表皮型ケラチン $(34 \beta \mathrm{E} 12)$ 陰性, 単層上皮型ケラチン（CAM5.2）陽性（図 1c), vimentin 陽性。

診断と考察：本症例は著明な腔形成を伴う異 型細胞の増殖で, 免疫組織化学的に単層上皮型 ケラチンが陽性であるため, 腺癌かどうか, 腺 癌であれば皮膚原発か転移かが問題になる。 vimentin 陽性の解釈も難しい。未分化 SCC は 紡錘形細胞や棘融解細胞を有し, vimentin 陽 性になる ${ }^{12)}$ 。最近ではモノクローナル抗ケラ チン抗体による検索により, 未分化 SCC は単 層上皮型ケラチンが陽性になることが知られて いる ${ }^{3)}$ 。本症例は表皮由来の腫瘍細胞が未分化 になり，主に紡錘形細胞として存在し，一部が 異常角化の結果, 棘融解による腔形成を示した と考えられる。

原発か転移か? SCC 関連症例のまとめ

- 表皮との連続のない境界明瞭な腫瘤では転移 を疑う。

-未分化 SCC では単層上皮型ケラチンが陽性 になり，腺癌との鑑別を必要とする。 

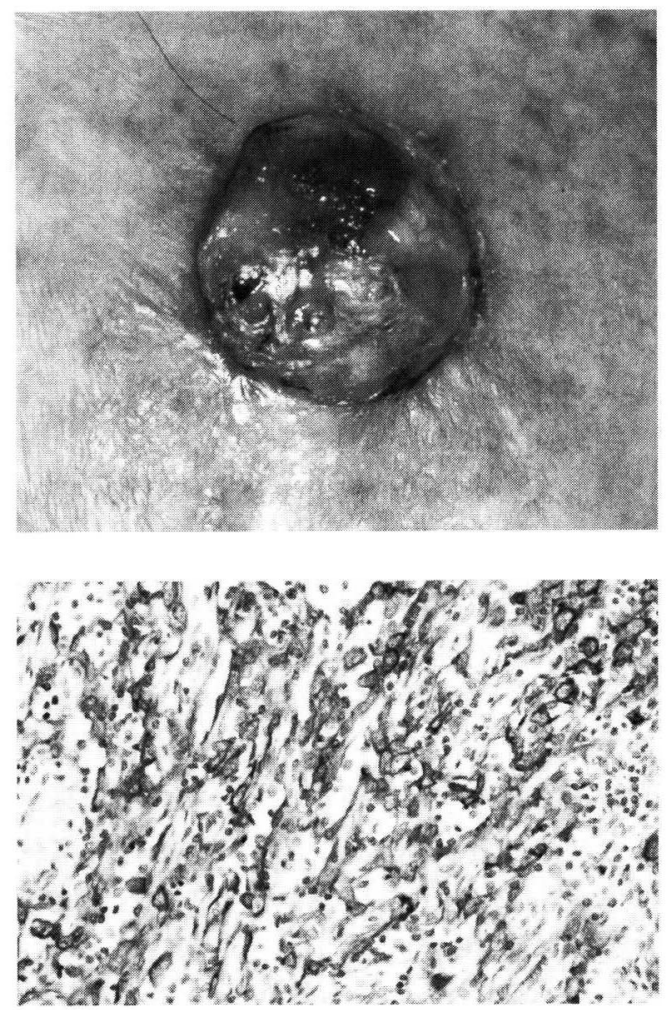

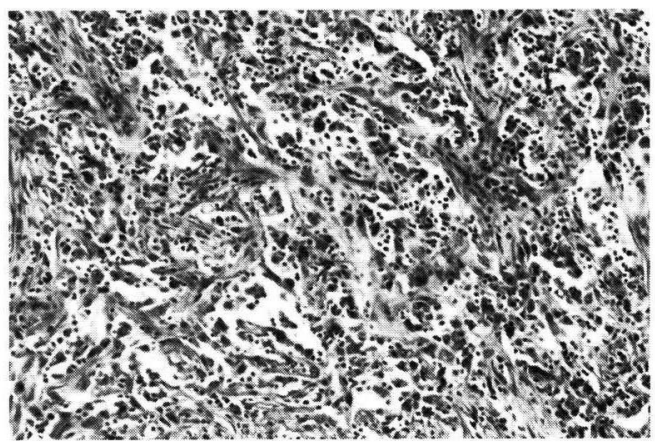

\begin{tabular}{l|l}
$\mathrm{a}$ & $\mathrm{b}$ \\
\hline $\mathrm{c}$ &
\end{tabular}

図 1. (症例 2)

a. $35 \times 28 \mathrm{~mm}$ 大，ドーム状に隆起する，びらんを伴う肉芽様腫瘤（臨床像，右㚘部）

b. 異型細胞が棘融解を起こし, pseudogland を形成している。癌真珠はない，腺癌に似る (HE 染色)

c. 単層上皮型ケラチンCAM5.2 陽性（免疫染色）

原発か転移かの最終判断は time course によ る。

\section{乳房外Paget 病および皮膚付属器癌} 関連症例

症例 $3: 72$ 歳, 男性

現病歴：9 年前, 膀胱移行上皮癌に対 L, 根 治的膀胱全摘術および尿管 S 状結腸吻合術を 施行された。約 1 年前, 亀頭部に皮疹が出現し た。

現 症：亀頭部に尿道口と連続するびらんを 伴う紅色皮疹がある（図 $2 \mathrm{a} ） 。$

病理組織：表皮下層中心に基底層を残し, Paget 細胞が個々あるいは胞巣を形成して存在 している。 extramammary Paget's disease の像
である。

免疫組織化学：CAM5.2 陽性, サイトケラチ ン 20（Ks20.8）陽性。

治療と経過：陰茥切断および尿道抜去術を施 行した。病理組織学的に外尿道口近傍の尿道粘 膜上皮内に Paget 細胞が存在し，その部分の尿 道粘膜固有層深部のリンパ管腔内に腫瘍塊が存 在していた（図 2 b)。それより中枢の尿道粘 膜上皮内に Paget 細胞はなかった。

診断と考察：本症例で注目すべきは真皮・尿 道粘膜固有層の哚部のリンパ管内における腫瘍 の存在と CK20 陽性である。これらから，膀胱 移行上皮癌がリンパ向性転移の後, 表皮向性転 移を生じたと考えられる。膀胱移行上皮癌は龟 頭部に表皮向性にパジェット現象を生じる4)。 $\mathrm{CK} 20$ は消化器腺癌, 膀胱移行上皮癌, メルケ 

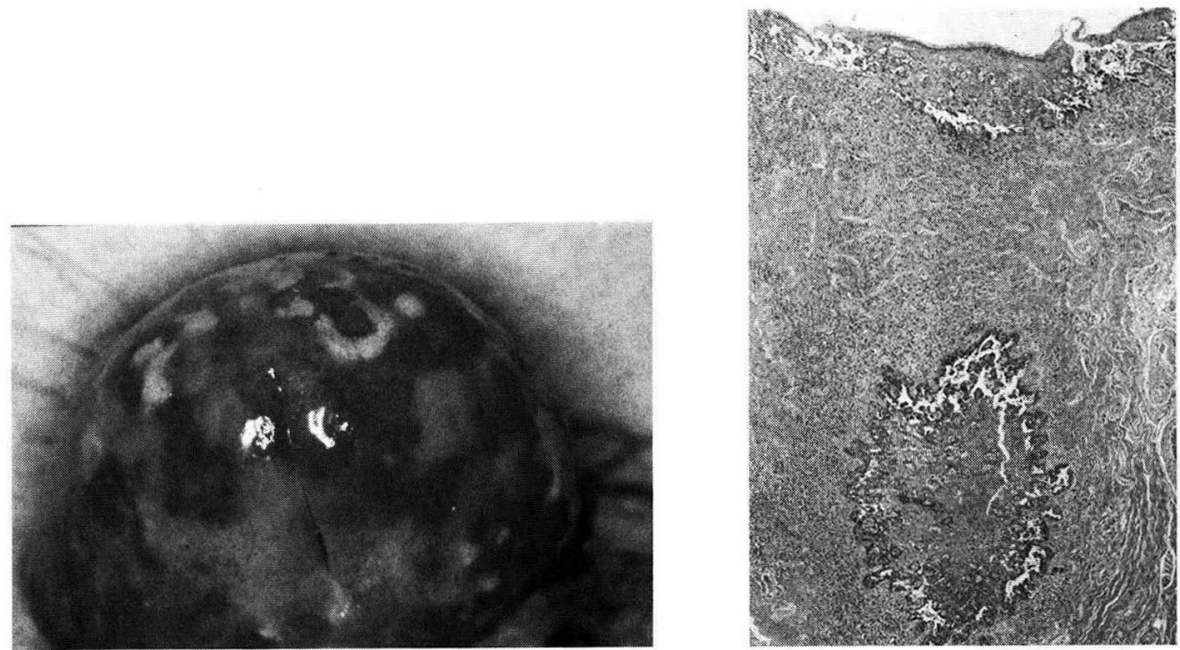

$\mathrm{a} \mid \mathrm{b}$

図 2.(症例 3 )

a. 尿道口と連続する。びらんを伴う紅色皮疹（臨床像，亀頭部）

b. 尿道粘膜上皮内および尿道粘膜固有層媣部のリンパ管䐑内に腫暗が存在している（HE 染色， 外尿道口近傍)

ル細胞癌を特異的に染色 ${ }^{5) 6)}$ ，鑑別に有用で ある。

症例 $4: 76$ 歳, 女性

現病歴：約 3 年前に発症。

現 症：肚囲にびらんを伴う紅斑がある。辺 縁には脱色素斑を伴っている。

病理組織：症例 3 と同様, extramammary Paget's disease の像である。

免疫組織化学 : C E A + /C K $7+/ C$ K $20+/$ GCDFP15－/PAS＋であった。

大腸内視鏡検査：肛門管癌の存在が確認され た。全切除後の標本で, 真皮深部のリンパ管腔 内に腫瘍細胞が存在していた。

診断と考察 : Paget 細胞は CK20+/GCDFP15であり，肚囲の真皮深部のリンパ管内に腫瘍細 胞が存在しており，肛門管癌が経上皮的あるい はリンパ向性に表皮行性転移を生じたと考えら れる。GCDFP15 は汗腺 - 乳腺 - 唾液腺を染色 するが，消化管は染色しない7)。肚囲パジェッ 卜現象は消化器腺癌の転移であることが多いた め, GCDFP15 と CK20 を染色することにより， 肛囲の Paget 病とパジェット現象の鑑別が可能 である ${ }^{8)}$
症例 5：73 歳, 男性

現病歴： 7 年前に発症。

現 症：右眼瞼に紅斑・腫脹・小結節がある (図 3 a)。

病理組織: 表皮との連続や表皮内病変はな い。真皮から皮下にかけて印鑑細胞が特別な構 造を形成せずに増殖している（図 $3 b ） 。$

免疫組織化学：多くの汗腺系マーカーととも に GCDFP15 + /CK20 + (図 3 c)。

各種画像検査：内臓悪性腫瘍はない。

診断と考察：CK20 は皮䖉原発のものではメ ルケル細胞癌のみを染色するため, 免疫染色所 見 $(\mathrm{GCDFP} 15+/ \mathrm{CK} 20+)$ も皮膚原発加転移 かの判断が難しい。内臓腺癌を合併しない眼瞼 原発の印鑑細胞癌が稀に存在し ${ }^{9)}$ - 12), 皮虑原 発であるにもかかわらずCK20が陽性にな $3^{13)}$ 。本症例は皮膚原発の印鑑細胞癌である。

原発か転移か? 乳房外 Paget 病, 付属器癌関 連症例のまとめ

- 膀胱癌, 子宮癌・胵癌, 直腸肛門癌が, 外陰 部や肛囲にパジェット現象を生じることがあ る。

•真皮・粘膜固有層の深部のリンパ管内腫瘍塞 

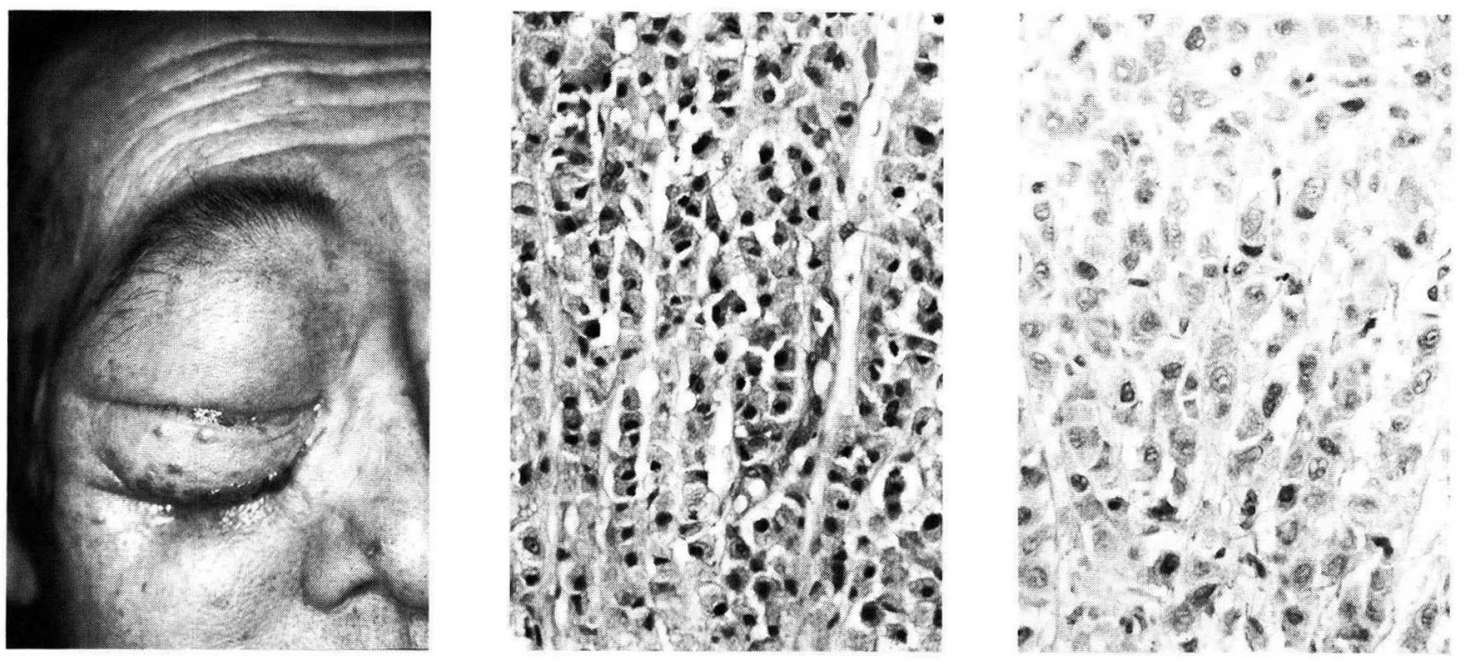

$\mathrm{a}|\mathrm{b}| \mathrm{c}$

図 3. (症例 5 )

a. 紅斑・腫脹・小結節（臨床像，右眼瞼）

b. 真皮から皮下にかけて signet ring cell が特別な構造を形成せずに増殖している（HE 染色）

c. サイトケラチン 20 陽性（免疫染色）

栓はパジェット現象を示唆する。

- Paget病とパジェット現象の鑑別にGCDFP15 と CK20 の染色が有用である。

- 眼瞼好発の皮䖉原発印鑑細胞癌が存在し, CK20 陽性である。

\section{悪性黒色腫関連症例}

\section{症例 6 : 74 歳, 男性}

現病歴：7〜8 年前, 左肩甲下部の ‘ホクロ’ を指摘されていた。前医の話によると“紫紅色 調の表面平滑なドーム状結節”であった。

現 症：前医での手術痕のみ。

病理組織：表皮内病変はなく, 境界明瞭な真 皮内結節である（図 4 ）。紡錘形の異型な腫瘍 細胞が密に増殖する。メラニン色素はない。

免疫組織化学：腫瘍細胞はS-100, NSE, MITF -M isoform陽性のメラノサイトであった。MART -1，HMB-45 は陰性であった。

各種画像検査：転移所見はない。

診断と考察：本症例は表皮内病変を伴わない 境界明瞭な皮内結節である点は転移性黒色腫に

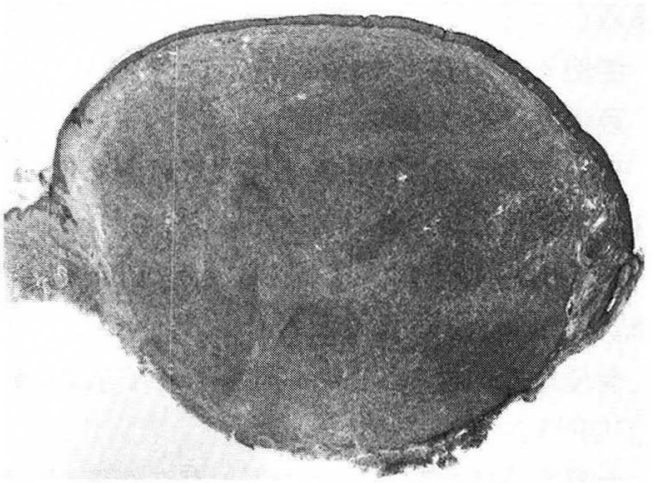

図 4. (症例 6)

表皮内病変のない境界明暸な真皮内結節，紡 鏵形の異型細胞が密に增殖し、メラニン色素 はない ( $\mathrm{HE}$ 染色, 信州大学 井出葉子先生ご 提供)

類似するが，各種検査で転移所見はなく，術後 2 年以上 disease free である点からは皮膚原発 が示唆される。表皮内および表皮真皮境界部に 病変を持たず，かつ前駆病変として母斑のない 皮内・皮下に限局する予後のよいメラノーマの 特殊型が存在することが知られており，原発性 真皮メラノーマ primary dermal melanoma な どと呼ばれている ${ }^{14) 15) 。 ~}$ 
症例 $7: 64$ 歳, 女性

現病歴： 7 年前に左下腿黒色結節を切除して いる。最近左背部に腫瘤が出現し, 徐々に増大 してきた。

現 症：左背部に $20 \times 15 \times 13 \mathrm{~cm}$ 大の潰瘍を 伴う, ドーム状暗褐色腫瘤がある。

病理組織：表皮は圧排されて潰瘍化している が, 表皮内病変や表皮との連続はない。豊富な 胞体を有する clear cell が胞巣を形成して増殖 し, clear cell sarcomaの像である。

免疫組織化学 : S-100+/HMB45+/Melan A+ 治療と経過：受診時すでに頸部痛があり， MRI で骨転移が確認された。すぐにDAC-Tam 療法, 放射線照射を開始したが受診 7 カ月後に 永眠した。clear cell sarcoma と考えた腫瘤が 原発で他蔵器転移を起こしたとは考えづらい急 速な経過であった。7 年前の左下腿の結節の標 本を確認したところ，悪性黒色腫であった。

診断と考察 : 本症例の特徴は clear cell sarcoma (malignant melanoma of soft parts) に 合致しているが, 実際には 7 年前の悪性黒色腫 の皮膚転移であった。clear cell sarcomaの特 徵を有するものが悪性黒色腫の転移であること が時に経験される。

症例 $8: 71$ 歳, 男性

現病歴：1998 年 1 月に上歯肉部正中に肉芽 様腫瘤が，2月に右肩背面に有茎性腫瘤が，4 月に背部中央に黒色結節が，6月に右大腿前面 に暗褐色結節が次々に出現, 8 月には永眠され た。上歯肉部の腫瘤は SCC と診断され放射線 照射をされていた。

現 症: (上歯肉部正中) $25 \times 17 \times 15 \mathrm{~mm}$ 大, 肉芽様の暗赤色腫瘤。(右肩背部) $10 \times 10 \mathrm{~mm}$ 大, 有茎性の暗赤色腫瘤。(背部中央) $9 \times$ $8 \mathrm{~mm}$ 大, 痂皮を伴う黒色結節。(右大腿前面) $10 \times 10 \mathrm{~mm}$ 大，不規則形の暗褐色結節。

病理組織：(上歯肉部正中）悪性黒色腫。（右 肩背部) 有茥性黑色腫に類似するが, 上皮襟形成 がみられ，表皮内メラノサイトの lateral spread はない。(背部中央) pagetoid melanomaに類 似。lateral spread がある。（右大腿前面）epidermotropic melanomaの像である。 lateral spreadはない。また, 主病変と離れて皮下脂 肪織内に密な腫瘍塊が存在する。血管あるいは リンパ管内侵襲もみられる。

診断と考察: 上歯肉部正中の腫瘤は初発で, 最も大きく，色素性病変の既往がないことから 原発であると考えられる。右肩背部の有茎性腫 瘤は, 襟形成があり, lateral spread がないため, 転移性黒色腫の可能性が高い。背部中央の結節 は原発性黒色腫に矛盾しない。右大腿前面の結 節は epidermotropic melanoma の像である。し かしながら time course からこれらすべてが歯 肉部原発悪性黒色腫からの転移であると考える のが自然である。epidermotropic metastatic malignant melanomaは当初は表皮内メラノサ イトの lateral spread がないこと, 辺縁での上 皮襟形成, 脈管内侵襲を有することが原発メラ ノーマとの鑑別点であるとされたが16)，その 後, 本症例の背部の病変のように lateral spread が真皮病巣を越えることや ${ }^{17)}$, 真皮病 巣が消退して表皮内病変のみとなることが報告 され ${ }^{18)}$, time course や全身検索などによる総 合的判断が最重要である。本症例も背部の病変 は経過からのみ転移性であると判断できた ${ }^{19) 。}$

原発か転移か? メラノーマ関連症例のまとめ

-原発性真皮メラノーマという表皮内病変を有 さない特殊型が存在する。

- clear cell sarcoma の臨床病理組織学的特徴 を有するものには原発と転移の 2 種類があ る。

- epidermotropic metastatic malignant melanoma は melanoma in situ に類似するこ とがある。

\section{最 後に}

$\mathrm{SCC}$ 関連では表皮との連続と周囲との境界 に注意すること, 未分化 SCC の特徴を理解す ることが重要である。乳房外 Paget 病や付属器 
癌ではパジェット現象に注意する必要があり， 免疫染色がかなり有用である。悪性黒色腫関連 では, 原発転移の判断が難しい特殊型を理解す る必要がある。

\section{文献}

1) Ikegawa $S$, et al : Vimentin-positive squamous cell carcinoma arising in a burn scar. Arch Dermatol, $125: 1672,1989$

2 ) Smith KJ, et al : Spindle cell neoplasms coexpressing cytokeratin and vimentin (metaplastic squamous cell carcinoma). J Cutan Pathol, 19:286, 1992

3 ) Watanabe $\mathrm{S}$, et al : Changes of cytokeratin and involucrin expression in squamous cell carcinomas of the skin during progression to malignancy. $\mathrm{Br} \mathrm{J}$ Dermatol, 132: 730, 1995

4 ) Metcalf JS, et al : Epidermotropic urothelial carcinoma involving the glans penis. Arch Dermatol, 121 :532, 1985

5 ) Moll R, et al: Cytokeratin 20 in human carcinomas: a new histodiagnostic marker detected by monoclonal antibodies. Am J Pathol, 140 : 427, 1992

6) Mittinen $M$ : Keratin 20 immunohistochemical marker for gastrointestinal, urothelial, and Merkel cell carcinomas. Mod Pathol, 8: 384, 1995

7 ) Goldblum JR, et al : Perianal Paget's disease : a histologic and immunohistochemical study of 11 cases with and without associated rectal adenocarcinoma. Am J Surg Pathol, 22 : 170, 1998

8 ) Nowak MA, et al: Perianal Paget's disease : distinguishing primary and secondary lesions using immunohistochemical studies including gross cystic disease fluid protein-15 and cytokeratin 20 expression. Arch Pathol Lab Med, 122 : 1077, 1998

9 ) Rosen $Y$, et al : Eccrine sweat gland tumor of clear cell origin involving the eyelids. Cancer, $36: 1034$, 1975

10) Grizzard WS, et al : Adenocarcinoma of eccrine sweat glands. Arch Ophthalmol, $94: 2119,1976$

11) Jakobiec FA, et al : Primary infiltrating signet ring carcinoma of the eyelids. Ophthalmol, $87: 29,1979$

12) Thomas JW, et al: Primary mucinous sweat gland carcinoma of the eyelid simulating metastatic carcinoma. Am J Ophthalmol, $87: 29,1979$

13) Kiyohara $T$, et al : Primary cutaneous signet ring cell carcinoma expressing cytokeratin 20 immunoreactivity. J Am Acad Dermatol, 54 : 532, 2006

14) Bowen GM, et al: Solitary melanoma confined to the dermal and/or subcutaneous tissue: evidence for revisiting the staging classification. Arch Dermatol, $36: 1397,2000$

15) Swetter SM, et al : Primary dermal melanoma. a distinct subtype of melanoma. Arch Dermatol, 140 : 99, 2004

16) Kornberg R, et al : Epidermotropically metastatic malignant melanoma : Differentiating malignant melanoma metastatic to the epidermis from malignant melanoma primary in the epidermis. Arch dermatol, $114: 67,1978$

17) Heenan PJ, et al : Epidermotropic metastatic melanoma simulating multiple primary melanoma. Am J Dermatopathol, 13:396, 1991

18) Abernethy JL, et al : Epidermotropic metastatic malignant melanoma simulating melanoma in situ. Am J Surg Pathol, 18: 1140, 1994

19) Hayashi H, et al : Epidermotropic metastatic malignant melanoma with a pedunculated appearance. Clin Exp Dermatol, 28: 666, 2003 